\title{
Komunikasi Ekspresi dalam Permainan Teater oleh Aktor Teater
}

\author{
Agustino, Sinta Paramita, Nigar Pandrianto \\ agustino.915150105@stu.untar.ac.id,sintap@fikom.untar.ac.id,nigarp@fikom.untar.ac.id
}

Fakultas Ilmu Komunikasi Universitas Tarumanagara

\begin{abstract}
Theatre is one of the art performances that people from various circles are interested in. This theatre game is played by actors who play characters according to the script given by the director. Communication becomes a factor in playing theatre, one of which is expression. Expressions not only to complement dialogue but also as a form of dialogue itself. Then a problem formulation appears, namely how to communicate expressions in theatre plays by theatre actors. This study aims to determine how theatre actors communicate expression in theatre plays. The theory used in this research is the cumulative structure theory. The approach used in this research is qualitative research. The research method used in this research is a case study using data collection methods in the form of interviews and observations. Data processing and analysis techniques used in this study are data reduction, data presentation, drawing conclusions and verification. The result of this research is the communication of expression is carried out by theatre actors by conveying a meaning and honesty from within. Forms of communication expression are facial expressions, gestures, and voices.
\end{abstract}

Keyword: actor, communication, expression, theatre

\begin{abstract}
Abstrak
Teater merupakan salah satu pertunjukan seni yang diminati oleh masyarakat dari berbagai kalangan. Permainan teater ini dimainkan oleh para aktor yang memerankan karakter sesuai dengan naskah yang diberikan oleh sutradara. Komunikasi menjadi salah satu faktor dalam bermain teater salah satunya adalah ekspresi. Ekspresi tidak hanya untuk pelengkap dialog tapi juga sebagai bentuk dari dialog itu sendiri. Maka muncul suatu rumusan masalah yakni bagaimana komunikasi ekspresi dalam permainan teater oleh aktor teater. Penelitian ini memiliki tujuan untuk mengetahui bagaimana aktor teater melakukan komunikasi ekspresi dalam permainan teater. Teori yang digunakan dalam penelitian ini adalah teori struktur Kumulatif. Pendekatan yang digunakan dalam penelitian ini adalah penelitian kualitatif. Metode penelitian yang digunakan dalam penelitian ini adalah studi kasus dengan menggunakan metode pengumpulan data berupa wawancara dan observasi. Teknik pengolahan dan analisis data yang digunakan dalam penelitian ini adalah reduksi data, penyajian data, mengambil kesimpulan dan verifikasi. Hasil dari penelitian ini adalah komunikasi ekspresi dilakukan oleh aktor teater dengan menyampaikan sebuah makna dan jujur dari dalam diri. bentuk dari komunikasi ekspresi merupakan ekspresi wajah, gerak tubuh, dan suara.
\end{abstract}

Kata kunci: aktor, ekspresi, komunikasi, teater

\section{Pendahuluan}

Teater diminati oleh banyak orang dari berbagai kalangan. Banyak kampus, dan sekolah yang menjadikan teater sebagai salah satu pelajaran atau extra kulikuler. Banyak institusi perkumpulan teater yang ada di Jakarta yang berisikan pekerja, mahasiswa dan siswa. Hal ini dapat menunjukan bahwa banyak orang yang peduli 
pada kesenian teater dan ingin memajukannya melalui berbagai pertunjukan, lomba, festival, dan workshop.

Berbeda dengan film, dalam teater pertunjukan yang disajikan tidak direkam dan tidak dapat diulang jika sudah ditampilkan. Maka dari itu, penampilan dalam teater dilatih terus menerus sehingga dapat menutup kemungkinan terjadi kesalahan saat pertunjukan berlangsung. Tentunya permainan panggung disajikan pastilah sesuai dengan skenario yang diberikan. Skenario tersebut berisikan cerita, nama tokoh, dan dialog yang akan dimainkan (Pendidikan, 2020).

Permainan panggung dalam teater tentunya membutuhkan latihan yang panjang. Tentunya juga berbeda dari pada film. Dalam teater, permainan panggung haruslah luas dan besar. Tidak ada batasan dari kamera. Penonton harus bisa melihat secara jelas seperti apa gerakan para aktor. Komunikasi tentu menjadi bagian penting dalam permainan teater. West dan Turner menjelaskan bahwa komunikasi merupakan proses sosial dari individu-individu dalam menggunakan simbol-simbol untuk menciptakan, menginterprestasikan sebuah makna dalam suatu pesan (Mufida dan Azeharie, 2020). Salah satu komunikasi yang digunakan adalah komunikasi nonverbal. Wood (2013) mengemukakan bahwa komunikasi non-verbal mencakup semua aspek komunikasi selain kata-kata.

Komunikasi non-verbal yang difokuskan dalam teater adalah ekspresi. Jika dilihat dari terminologinya ekspresi adalah proses komunikasi melalui media yang bertujuan untuk membentuk persamaan persepsi akan pesan yang ingin dikomunikasikan. Sedangkan menurut disiplin ilmu arsitektur ekspresi memiliki 3 komponen seperti pesan, media, dan penerima atau khalayak. Tidak hanya itu, ekspresi juga dapat dimengerti sebagai ungkapan dari macam-macam bahasa tubuh (Dosen Pendidikan, 2020). Keselarasan dari gerakan, ekspresi, emosi, dan juga dialog merupakan kunci penting dalam permainan para aktor. Maka dari itu permainan panggung tidak bisa dibilang mudah, tetapi juga tidak susah.

Teknik pelatihan dan improvisasi menjadi faktor dalam permainan panggung. Aktor tentunya juga harus bisa beradaptasi di atas panggung jika terjadi kesalahan atau kecelakan panggung. Saat itulah teknik yang dilatih dan improvisasi dibutuhkan oleh aktor. Dengan teknik dan improvisasi, kesalahan permainan panggung dapat ditutup oleh aktor. Sehingga penonton tidak mengetahui bahwa terjadi sebuah kesalahan dalam panggung (Ilmu Seni, 2020). Semua itu membuat permainan panggung menjadi sangat penting. Tentunya aktor-aktor dalam teater harus bisa memberikan permainan panggung yang menarik dan unik. Tanpa keunikan tentunya semua permainan panggung akan terlihat sama. Untuk mencari semua itu, tentu diperlukan sebuah riset tentang komunikasi yang tidak menggunakan kata-kata atau komunikasi nonverbal.

Dengan latar belakang tersebut rumusan masalah penelitian ini adalah bagaimana komunikasi ekspresi dalam permainan teater oleh aktor teater. Tujuan penelitian adalah untuk mengetahui bagaimana komunikasi ekspresi dalam permainan teater oleh aktor teater, bagaimana komunikasi ekspresi dilakukan oleh aktor teater dalam permainan teater, dan bagaimana bentuk-bentuk dari komunikasi ekspresi Penelitian ini menggunakan teori struktur kumulatif. Peneliti menggunakan teori ini dikarenakan teori ini lebih banyak membahas tentang gerak tubuh dan ekspresi wajah. 


\section{Metode Penelitian}

Pada penelitian ini peneliti menggunakan penelitian tipe deskriptif kualitatif. Penelitian kualitatif adalah sebuah penelitian yang dipergunakan untuk menjelaskan dan menganalisis fenomena, peristiwa, aktivitas sosial, sikap, kepercayaan, persepsi, dan pemikiran orang secara individual maupun kelompok (Bachri, 2010). Penelitian kulaitatif menggunakan teknik analisis mendalam (in-depth analysis), yang mempelajari masalah secara kasus perkasus karena sifat satu masalah akan berbeda dengan sifat dari masalah lainnya. Penelitian deskriptif adalah metode penelitian yang menggambarkan suatu gejala, peristiwa, atau kejadian yang sedang terjadi pada masa sekarang, penelitian ini berfokus kepada pemecahan masalah-masalah sebagaimana adanya saat penelitian dijalankan (Soendari, 2010).

Dalam penelitian ini peneliti mengumpulkan data dengan melakukan pengamatan dengan seksama terhadap objek yang diteliti, mencakup penjelasan detail yang disertai catatan-catatan dari hasil wawancara dengan partisipan. Metode penelitian yang digunakan peneliti merupakan metode penelitian kualitatif dengan pendekatan studi kasus. Penelitian kualitatif tidak diperoleh melalu prosedur statistik atau bentuk hitungan lainnya. Penelitian kualitatif justru dilakukan dengan memahami dan mengartikan makna suatu peristiwa interaksi dalam suatu situasi tertentu menurut perspektif peneliti. Subjek digunakan oleh peneliti adalah aktor, sutradara, dan penikmat teater dengan rentang usia 18 - 42 tahun dengan latar belakang yang berbeda. Peneliti menggunakan metode pengumpulan data berupa wawancara dan observasi. Teknik pengolahan dan analisis data berupa reduksi data, penyajian data, mengambil kesimpulan dan verifikasi.

\section{Hasil Temuan dan Diskusi}

Observasi dilakukan pada hari Jumat, 27 November 2020. Kegiatan ini merupakan kegiatan latihan baca naskah yang dilakukan oleh teater Sentra untuk anggota baru dengan menggunakan aplikasi Ms Teams. Latihan ini diawali oleh ketua umum yang menanyakan tentang materi latihan dua minggu yang lalu. Disini penulis memperhatikan wajah dari Fionny, Jeffrey, dan Christie yang merupakan anggota baru Teater Sentra. Di sini peneliti melihat Fionny dan Jeffrey selalu tersenyum sedangkan Christie hanya berekspresi datar. Jeffrey mencoba memberi contoh pada latihan tersebut, dan dilanjutkan oleh pelatih teater Sentra. Diawal sebelum masuk kepada kegiatan utama mereka yaitu membaca naskah. Peneliti melihat bahwa rata-rata Fionny, Jeffrey, dan Christie selalu senyum disaat ditanya oleh pelatih dan mereka juga mencoba menjawab sebisa mereka saat ditunjuk.

Setelah beberapa lama akhirnya kegiatan membaca naskah dimulai. Disini pelatih menanyakan apakah ada yang tahu apa gunanya kegiatan membaca naskah. Christie, Jeffrey, dan Aljazira mencoba menjawab dan Valentino yang ditunjuk oleh pelatih. Penulis melihat bahwa para peserta memerhatikan apa yang dikatakan pelatih tapi mereka masih terlihat malu-malu. Membaca naskah ini menggunakan naskah berjudul Demokrasi. Pelatih akan menunjuk pemain baru yang akan menjadi tokoh pada naskah tersebut dan akan bergantian setiap act.

Pada Act 1 Dianyi membaca sebagai Mentri. Peneliti melihat Dianyi hanya membaca dialog yang diberikan tanpa adanya ekspresi dan emosi. Act 2 terdapat tokoh A yang diperankan Aljazira, Rakyat oleh Yosie, Ajudan oleh Jeffrey, dan Kepala Sekolah oleh Fakhri. Pada act 2, para peserta yang ditunjuk sudah mencoba 
mulai memasukan karakter pada tokoh yang diperankan, tapi mereka masih tidak terlihat ekspresinya. Selesai act 2 pelatih mulai menjelaskan tentang masing-masing tokoh dari naskah Demokrasi. Pelatih melakukan ini supaya para peserta mengetahui karakter dari tokoh-tokoh tersebut.

Pada Act 3 terdapat B yang diperankan Valentino, Ajudan oleh Herliany. A oleh Fionny, dan C oleh Cindy. Disini Fionny sebagai A dan Valentino sebagai B sudah mulai terlihat ekspresinya, sedankan ajudan ekspresinya masih terlihat kecil dan juga $\mathrm{C}$ yang tidak terlihat ekspresinya. Pada Act 4 terdapat B oleh Yusianne, A oleh Sharleen, C oleh Jessica, Teman 1 oleh Chintya dan Teman 2 oleh Nazareth. Pada act ini semua ekspresi pemain terlihat kecil sekali, tapi mereka sudah dapat memainkan intonasinya.

Pada Act 5 terdapat A oleh Natasya, C oleh Archangela tapi dikarekan Archangela memiliki masalah dengan mic maka digantikan oleh Putri, X oleh Catherina, dan Y oleh Khairunnisa. Ditengah dialog, pelatih Kembali memberikan contoh pada tokoh yang dimainkan oleh peserta. Di sini ekspresi masih saja kurang terlihat dengan jelas dan hanya terlihat seperti membaca saja, walau begitu intonasi suara mereka sudah dapat mereka mainkan tapi masih kurang ekspresi. Pada Act 6 pada bagian ini terdapat A oleh Valentino, C oleh Eunike, Anak oleh Gracealla, Istri/Suami oleh Rivaldo, Kakek oleh Timoti, Y oleh Vira dan X oleh Tiyas. Disini hanya Valentino dan Timoti yang dapat dilihat ekspresinya dikarenakan peserta lain tidak menyalakan Web Camera mereka. Valentino sudah terlihat memainkan ekspresi dan intonasinya sedangkan Timoti masih terlihat malu-malu.

Pada Act 7 terdapat kakek yang diperankan oleh Christie, Mentri oleh Michelle, A oleh Florencia, B oleh Archangela, X oleh Jeffrey, dan Y oleh Sherleen. Disini ekspresi masih saja kurang terlihat jelas, Sharleen sebagai Y memiliki ekspresi yang jelas, Christie, Florencia, Jeffrey, dan Archangela masih belum terlihat ekspresinya tapi sudah memainkan intonasi suara mereka. Setelah semua act selesai, pelatih kembali memberi arahan dan masukan tentang pembentukan tokoh yang kedepannya akan mereka dapat.

Teori Struktur Kumulatif adalah teori yang memiliki fokus analisis pada makna yang diasosiasikan dengan kinesic. Dalam teori ini Ekman dan Friesen beranggapan bahwa komunikasi nonverbal menampilkan dua hal yaitu apakah suatu tindakan itu disengaja dan apakah tindakan tersebut harus menyertai komunikasi verbal (Rahayu, 2019) Saat orang senang maka dia akan tersenyum dan mengangkat tangannya keatas atau bisa juga melompat. Semua dilakukan dengan raut wajah dan gerakan tubuh.

Pada teater, para aktor tentu haruslah membaca naskah yang diberikan oleh sutradara. Naskah tersebut memiliki dialog yang dimana harus ditafsirkan oleh para aktor, seperti apa penyampaiannya, seperti apa tokoh yang diperankan, apa itu dialog senang atau sedih, para aktor haruslah menafsirnya sehingga komunikasi ekspresi tercipta sesuai dengan kebutuhan naskah. Hal ini menegaskan bahwa komunikasi ekspresi ini dilakukan secara sengaja, karena aktor mencari arti dari dialog yang diberikan, mencari rasa yang disarakan dan apa yang menyebabkan tokoh tersebut merasakan seperti itu.

Tentunya aktor harus mencari seperti apa komunikasi ekspresi yang pas dengan budaya dari mana tokoh tersebut berasal. Ini dikarenakan setiap negara dapat memiliki komunikasi ekspresi yang berbeda seperti negara jepang yang membungkukan badan saat menyapa dan meminta maaf tapi di Indonesia tidak harus membungkukan badan saat menyapa dan meminta maaf. Karenakan sifat komunikasi 
yang ambigu, aktor dapat menggunakan komunikasi ekspresi untuk menggantikan, menguatkan, bahkan menentang dialog atau kata - kata yang ada dengan ekspresi wajah dan gerakan tubuh aktor tersebut. Komunikasi ekspresi selain dapat memperkuat pesan verbal yang disampaikan tapi juga dapat berdiri sendiri tanpa ada pesan verbal.

Tentunya penyampaian komunikasi ekspresi yang baik haruslah jelas dan jujur dari dalam diri sendiri sehingga ambiguitas dapat berkurang, maka dari itu penonton yang berkomunikasi dengan aktor akan dapat mengerti apa yang dimaksud oleh aktor dengan baik. Contoh yang kita dapat lihat adalah dalam teater, bagaimana seorang aktor merespon atau menyampaikan sebuah pesan "Kamu lapar?" dapat dijawab hanya dengan menggelengkan kepala, "Kamu suka aku?" dapat dijawab dengan menganggukkan kepala, atau "Aku mau makan." Dapat dikomunikasikan dengan kita menunjuk diri sendiri dengan tangan kita lalu tangan bergerak seperti sedang menggunakan sendok dan garpu atau makan dengan tangan (sesuai dengan kenyamanan dari masing - masing orang) dan ekspresi wajah kita bergerak seakan kita sedang makan. Maka dari itu orang lain akan tau kalau kita mau makan. Menangis, marah, Bahagia, atau kaget dapat dilakukan tanpa adanya pesan verbal.

Tentu saja aktor juga dapat mengulang ataupun menekankan pesan verbal dengan komunikasi ekspresi, hal ini tentu akan membuat pesan apa yang ingin disampaikan oleh sang aktor akan menjadi lebih jelas. Tapi sering juga pesan yang ingin disampaikan oleh aktor dapat berbeda dengan ekspresi yang ditunjukan, ini menunjukan bahwa ada maksud tersembunyi atau ada sesuatu yang ditutupi oleh tokoh aktor tersebut. Aktor juga dapat mengatur interaksi antar tokoh dengan komunikasi ekspresi seperti menggerakkan tangan untuk menyuruh aktor lain diam. Dengan komunikasi ekspresi, aktor juga dapat memperlihatkan hubungan antara tokoh yang meraka perankan kepada penonton sehingga mereka tidak harus menyatakan sebagaimana hubungan tokoh tersebut tapi mereka juga tetap dapat memberitahukan seperti apa hubungan antar tokoh. Semua itu dilakukan oleh aktor pada proses melatih tokoh, sehingga pada saat penampilan panggung para tokoh dapat membuat penonton masuk kedalam cerita dari naskah yang dimainkan.

\section{Simpulan}

Komunikasi ekspresi adalah komunikasi yang menyampaikan sebuah makna, atau perasaan dari sebuah pesan dengan ekspresi wajah atau gerakan tubuh. Komunikasi ekspresi dalam permainan teater yang dilakukan dengan sengaja dan komunikasi ekspresi dapat dilakukan tanpa adanya pesan verbal. Komunikasi sangat penting dalam sebuah dialog dan komunikasi ekspresi yang baik adalah komunikasi yang menyampaikan sebuah makna dan jujur dari dalam diri.

Dalam melatih tokoh atau komunikasi ekspresi dapat dilakukan dengan berbagai cara, kita dapat membaca naskah berung kali, kita dapat melakukan observasi, kita dapat bereksplorasi, kita dapat menanyakan perihal dialog, tokoh, kepada sutradara atau teman aktor kita, kita dapat menonton permain dari teater lain lalu menjadikannya sebagai refrensi dan yang pasti kita harus melatih apa yang sudah kita dapatkan. Bentuk utama dari komunikasi ekspresi dalam teater adalah tubuh. Tubuh dapat memunculkan hal - hal berupa gerak, suara, dan ekspresi wajah atau rawut muka yang semua berfokus kepada mata. 


\section{Ucapan Terima Kasih}

Penulis ingin mengucapkan kepada seluruh narasumber wawancara dan observasi dalam penelitian ini. Terima kasih juga kepada semua pihak yang telah membantu peneliti dalam proses penelitian ini.

\section{Daftar Pustaka}

Bachri, B. S. (2010) Meyakinkan Validitas Data Melalui Triangulasi Pada Penelitian Kualitatif. Teknologi Pendidikan, 10, 46-62. Oktober 25, 2020.

Dosen Pendidikan. (2020). "Ekspresi" Pengertian. Diakses dari https://www.dosenpendidikan.co.id/pengertian-ekspresi-dan-jenis/ pada 25 September 2020.

Ilmu Seni (2020). Pengertian Improvisasi dalam Teater - Jenis dan fungsinya. Diakses dari https://ilmuseni.com/seni-pertunjukan/seni-teater/pengertianimprovisasi-dalam-teater/ pada 22 Oktober 2020.

Mufida, Y Nahria., \& Azeharie, Suzy S. (2020). Pengungkapan Diri Anak Tunarungu Dalam Kelompok Teater Tujuh di Jakarta. Koneksi, 4(1), 106-111. Diakses di https://journal.untar.ac.id/index.php/koneksi/article/view/6623

Pendidikan. (2020). Pengertian Seni Teater. Diakses dari https://pendidikan.co.id/pengertian-seni-teater/ pada 22 Oktober 2020.

Rahayu, Kiki. (2019). Aktivitas Komunikasi Nonverbal Guru Pada Anak Tunagrahita Dalam Proses Belajar Mengajar (Studi Pada Guru SDLB Negeri Kedungkandang). Undergraduate (S1) thesis, University of Muhammadiyah Malang.

Soendari, T. (2010). Metode Penelitian Deskriptif. Bandung: Universitas Pendidikan Indonesia.

Wood, Julia T. (2013). Communication Mosaics an Introduction to The Field of Communication. Boston, Massachusetts: Cengage Learning. 